\title{
Consideration in treatment decisions for refractory Mycoplasma pneumoniae pneumonia
}

\author{
Hye-Kyung Cho, MD, PhD \\ Department of Pediatrics, Gil Medical Center, Gachon University College of Medicine, Incheon, Korea
}

Mycoplasma pneumoniae (MP) is the most common cause of childhood bacterial pneumonia. Although macrolide is known to be effective as a first-line therapy, the proportion of macrolide resistance in MP pneumonia has strikingly increased during recent 2 decades in East Asia. This is challenging to physicians since they have to decide more often whether to use secondary treatment. Diagnostic methods to detect macrolide-resistance of MP are currently not available in Korean hospitals. Even in the diagnosis of MP infection, both serologic and molecular test have limitation: inability to differentiate current illness from carriage or asymptomatic infection. Combining these 2 diagnostic methods and excluding infection caused by other respiratory pathogens allow a more reliable diagnosis. This effort is even more demanding in recent years to keep children from unnecessary exposure to secondary antibiotics. Although several observational studies have reported that tetracycline and fluoroquinolone, which are considered in the treatment of refractory MP pneumonia, have efficacy of shortening the duration of fever and respiratory symptoms, those findings need to be proven by well-designed prospective studies. The use of tetracycline and fluoroquinolone in children is generally tolerable, as supported by many observational data. However, since concerns about side effects still remain, careful consideration about benefits and risks is needed to decide their use.

Key words: Mycoplasma pneumoniae, Child, Fluoroquinolone, Tetracycline

\section{Key message}

- To avoid unnecessary exposure to secondary antibiotics, it is needed to diagnose Mycoplasma pneumoniae (MP) pneumonia carefully, especially when unresponsiveness to macrolide is suspected.

- Serologic and molecular tests for MP infection and excluding respiratory infection caused by other pathogens might be considered.

- It is necessary to continuously monitor antibiotic susceptibility of MP, and efforts to lower antibiotic pressure are required.

\section{Introduction}

Mycoplasma pneumoniae (MP) is the most common cause of childhood bacterial pneumonia, and is a major consideration when choosing empirical antibiotics for treatment of community acquired pneumonia in children. ${ }^{1)}$ Epidemics usually occur in the endemic area every 3-7 years, ${ }^{2)}$ especially common in East Asia. In Korea, the recent epidemics of MP pneumonia were in 2011 and 2015. ${ }^{3)}$ Mycoplasmas lack cell walls and are intrinsically resistant to antimicrobial agents that target cell wall synthesis, such as $\beta$-lactams. ${ }^{4,5)}$ Macrolide and tetracycline, which inhibit protein synthesis by acting on bacterial ribosomes, and fluoroquinolone, which inhibits bacterial DNA replication, are intrinsically active against MP. Macrolide is primarily used for the treatment of children due to the potential toxicity of tetracycline and fluoroquinolone in young age. ${ }^{6}$ MP infection is known to respond well to macrolide antibiotics. Recently, however, there has been an increased incidence of MP infections caused by macrolide-resistant bacteria, which is associated with the development of severe progressive pneumonia.

Although the use of secondary antibiotics (tetracycline and fluoroquinolone), corticosteroids, or immunoglobulin has been considered as an alternative treatment for macrolide-resistant cases, ${ }^{7,8)}$ there have been some concerns about their efficacy and safety. In the current situation where there are limitations to the diagnosis of macrolide-resistant MP infections or even $\mathrm{MP}$ infections, there is an increasing concern about overuse and misuse as the use of these drugs increases during the epidemic.

In this review, we will discuss what to consider when diagnosing refractory MP pneumonia, and the efficacy and safety of second-line drugs for the proper use of second-line therapy.

\section{Macrolide-resistant MP and recent epidemiology}

MP has macrolides-binding sites to nucleotides in domains II and/or V of $23 \mathrm{~S}$ ribosomal RNA (rRNA) in the $50 \mathrm{~S}$ bacterial ribosomal subunit. Macrolide blocks the growth of the peptide chain at the early stages of protein synthesis and inhibits the

Corresponding author: Hye-Kyung Cho, MD, PhD. Department of Pediatrics, Gachon University Gil Medical Center, Gachon University College of Medicine, 21 Namdongdae-ro 774 beongil, Namdong-gu, Incheon 21565, Korea 
assembly of new large ribosomal subunits, resulting in gradual depletion of functional ribosomes in the cell. Several point mutations (positions 2063, 2064, 2067, and 2617 in the peptidyl transferase loop of $23 \mathrm{~S}$ rRNA) and insertions or deletions in ribosomal proteins L4 and L22 are involved in macrolide resistance in MP. ${ }^{5,910)}$ The most common transition mutation is A2063G followed by A2064G. The MP strains that carry the A2063G or A2064G mutation at the domain V of 23S rRNA exhibited very high minimal inhibitory concentrations (MICs) against all macrolides. ${ }^{4}$

The macrolide resistance of MP, which has emerged from the 2000s, gradually increased in frequency and reached more than $90 \%$ in 2011 depending on the region (Table 1). In Korea, it was reported that clonal expansion of $\mathrm{P} 1$ type 1 and sequence type (ST) $3 \mathrm{MP}$ with macrolide resistance contributed to the spread. ${ }^{11)}$ Similar patterns have been observed in neighboring countries, Japan and China, that P1 type 1 and ST3 or multiplelocus variable-number tandem repeat analysis type 4-5-7-2 has been predominated in MP infection and has contributed to increase of the resistance. Very recently, the proportion of P1 type 2 variants MP infections, which is usually susceptible to macrolide, has increased with the overall resistance rate slightly decreased. However, since the resistance rate among all type 2 MP has increased, it needs to be observed in the upcoming years. In Japan, the use of tetracycline or tosufloxacin has been recommended for the treatment of children with macrolideresistant MP pneumonia since the large epidemic in 2011. As a result, the use of macrolide has decreased, ${ }^{12)}$ and the ratio of macrolide-resistant MP has been decreasing since 2015.13-15) In
Europe and America, where the incidence of MP is not high, the macrolide-resistance rate still remains low, but the resistance rate in the United States has been gradually rising. ${ }^{9,16,17)}$

\section{Why should we distinguish between macrolide- resistant MP and refractory MP infection?}

\section{Difficulties in laboratory diagnosis of macrolide-resistant MP infection}

The diagnosis of macrolide-resistant MP infection can be made by measuring the MIC of strains isolated by culture or by detecting the point mutation of $23 \mathrm{~S}$ rRNA by polymerase chain reaction (PCR). The MICs of each antimicrobial can be determined by a microdilution method. ${ }^{3)}$ The criteria for drug-resistant MP, proposed by the Japanese Society for Mycoplasmology, ${ }^{18)}$ is MICs of $\geq 16 \mu \mathrm{g} / \mathrm{mL}$ for erythromycin, clarithromycin, and azithromycin. ${ }^{18)}$ Among the 36 isolates of macrolide-resistant MP from Korean children, 2010-2015, the $\mathrm{MIC}_{50} / \mathrm{MIC}_{90}$ values for erythromycin, clarithromycin, and azithromycin were $16 / 128 \mu \mathrm{g} / \mathrm{mL}, 64 / 128 \mu \mathrm{g} / \mathrm{mL}$, and $8 / 16 \mu \mathrm{g} / \mathrm{mL}$, respectively, which were higher than those for 23 macrolide-susceptible MP isolates, with $\mathrm{MIC}_{50} / \mathrm{MIC}_{90}$ values of $0.001 / 0.002 \mu \mathrm{g} / \mathrm{mL}$ for erythromycin, $0.001 / 0.002 \mu \mathrm{g} / \mathrm{mL}$ for clarithromycin, and $0.001 / 0.001 \mu \mathrm{g} / \mathrm{mL}$ for azithromycin. ${ }^{3)} \mathrm{In}$ a recent study on MP isolates retrieved from Japanese children, 2011-2016, $\mathrm{MIC}_{50} / \mathrm{MIC}_{90}$ of erythromycin, clarithromycin, and azithromycin for macrolide-resistant MP was $>128 />128$, $>128 />128$, and $32 / 64 \mu \mathrm{g} / \mathrm{mL}$, respectively, while those for

Table 1. Prevalence and genotype distribution of macrolide-resistance Mycoplasma pneumoniae in pediatric patients with respiratory tract infection from the studies published from 2018-2020

\begin{tabular}{|c|c|c|c|c|c|c|c|}
\hline Nation & Study & Study period & $\begin{array}{l}\text { Cases } \\
\text { studied } \\
\text { macrolide } \\
\text { resistance } \\
\quad(\mathrm{n})\end{array}$ & $\begin{array}{l}\text { Prevalence of } \\
\text { macrolide } \\
\text { resistance } \\
(\%)\end{array}$ & ST/MLVA type (\%) & P1 type & $\begin{array}{l}\text { Identified mutations } \\
\text { among MRMP } \\
\text { (\%) }\end{array}$ \\
\hline \multirow[t]{8}{*}{ China } & Guo et al. ${ }^{62)}$ & 2014 & 341 & 69.2 & ND & $\begin{array}{l}\text { Type } 1,87.7 \% \text {; type } 2 \text {, } \\
12.3 \%\end{array}$ & $\begin{array}{l}\text { A2063G (58.4\%), A2064G } \\
(7.3 \%)\end{array}$ \\
\hline & Qu et al. ${ }^{63)}$ & 2010-2012 & 88 & 94.3 & $\begin{array}{l}\text { M4-5-7-2 (86.4\%), M3-5-6-2 } \\
\text { (9.1\%); M4-5-7-2 predominated } \\
\text { in MRMP }\end{array}$ & $\begin{array}{l}\text { Type } 1 \text {, } 92.0 \% \text {; type } 2 \text {, } \\
8.0 \% \text {; type } 1 \text { predomi- } \\
\text { nated in MRMP }\end{array}$ & A2063G (100\%) \\
\hline & Xue et al. ${ }^{64)}$ & 2016 & 186 & 76.3 & $\begin{array}{l}\text { M4-5-7-2 (72.1\%), M3-5-6-2 } \\
(22.1 \%), \text { M4-5-7-3 (4.1\%), M4-5- } \\
\text { 5-2 (1.2\%), M3-6-6-2 (0.6\%) }\end{array}$ & $\begin{array}{l}\text { Type } 1,78.6 \% \text {; type } 2 \text {, } \\
21.4 \%\end{array}$ & $\begin{array}{l}\text { A2063G (74.1\%), mixed } \\
(2.7 \%)\end{array}$ \\
\hline & Yan et al. ${ }^{65)}$ & 2014-2015 & 200 & 90.5 & $\begin{array}{c}\text { M4-5-7-2 (87.5\%), M3-5-6-2 } \\
\text { (10.0\%), M4-5-6-2 (1.0\%), M4-5- } \\
\text { 7-3 (1.0\%), M4-5-5-2 (0.5\%) }\end{array}$ & $\begin{array}{l}\text { Type } 1,89.5 \% \text {; type } 2 \text {, } \\
10.5 \%\end{array}$ & $\begin{array}{l}\text { A2063G (89\%), A2064G } \\
(1 \%), \text { A2063T (0.5\%) }\end{array}$ \\
\hline & Yan et al. ${ }^{66)}$ & 2013-2017 & 423 & 91.0 & $\begin{array}{l}\text { M4-5-7-2 (87.5\%), M3-5-6-2 } \\
(11.3 \%), \text { M4-5-6-2 (0.5\%), M4-5- } \\
\text { 7-3 (0.5\%), M4-5-5-2 (0.2\%); M3- } \\
\text { 5-6-2 increasing across the study } \\
\text { period; M4-5-7-2 predominated } \\
\text { in MRMP }\end{array}$ & $\begin{array}{l}\text { Type } 1,88.2 \% \text {; type } 2 \\
\text { increasing across the } \\
\text { study period }\end{array}$ & Not specified \\
\hline & Yuan et al. ${ }^{67)}$ & 2016 & 120 & 90 & ND & ND & A2063G (90\%) \\
\hline & Zhao et al. ${ }^{68)}$ & $2014-2016$ & 81 & 65.4 & $\begin{array}{l}\text { M4-5-7-2 (51.9\%), M3-5-6-2 } \\
(39.5 \%)\end{array}$ & $\begin{array}{l}\text { Type } 1 \text { associated with MR; } \\
\text { type } 2 \text { increasing, but } \\
\text { MRMP proportion of type } \\
2 \text { isolates also increasing }\end{array}$ & $\begin{array}{l}\text { A2063G (98.1\%), A2064G } \\
(1.9 \%)\end{array}$ \\
\hline & Zhao et al. ${ }^{69)}$ & 2015-2018 & 1,045 & 29.4 & ND & ND & Not specified \\
\hline
\end{tabular}


Table 1. Continued

\begin{tabular}{|c|c|c|c|c|c|c|c|}
\hline Nation & Study & Study period & $\begin{array}{l}\text { Cases } \\
\text { studied } \\
\text { macrolide } \\
\text { resistance } \\
\text { (n) }\end{array}$ & $\begin{array}{l}\text { Prevalence of } \\
\text { macrolide } \\
\text { resistance } \\
\text { (\%) }\end{array}$ & ST/MLVA type (\%) & P1 type & $\begin{array}{c}\text { Identified } \\
\text { mutations among } \\
\text { MRMP (\%) }\end{array}$ \\
\hline \multirow[t]{7}{*}{ Japan } & Akashi et al. ${ }^{70)}$ & 2016-2017 & 222 & 65.3 & ND & ND & Not specified \\
\hline & Ando et al. ${ }^{71) a)}$ & $2002-2016$ & 417 & $\begin{array}{l}7-23(2002-2005) / \\
41-57(2006-2010) / \\
66-73(2011-2012) / \\
76(2015) / 35(2016)\end{array}$ & $\begin{array}{l}\text { MRMP: ST3 (74.6\%), ST19 } \\
\text { (11.4\%) } \\
\text { MSMP: ST3 (52.6\%), ST14 } \\
\text { (28.4\%) }\end{array}$ & Prevalence not specified & $\begin{array}{l}\text { A2063G (88.1\%), } \\
\text { A2063T (5.4\%), } \\
\text { A2064G (5.4\%), } \\
\text { A2063C (0.6\%), } \\
\text { C2617A (0.6\%) }\end{array}$ \\
\hline & $\begin{array}{l}\text { Katsukawa et } \\
\text { al. }{ }^{13)}\end{array}$ & 2011-2017 & 419 & $\begin{array}{l}71-82(2011-2014) / \\
41-50(2015-2017)\end{array}$ & ND & $\begin{array}{l}\text { Type } 1 \text { predominated in } \\
2011-2014 \text {, type } 2 \\
\text { increased from } 2015\end{array}$ & A2063G (49.9\%) \\
\hline & Kawakami et al. ${ }^{72)}$ & 2015-2016 & 137 & 58.4 & ND & ND & $\begin{array}{c}\text { A2063G (98.7\%), } \\
\text { A2064G (1.3\%) }\end{array}$ \\
\hline & Kenri et al. ${ }^{73)}$ & 2006-2019 & 554 & $\begin{array}{l}0(2006-2007) / \\
92.2(2012) / \\
2.6(2018) / \\
40(2019)\end{array}$ & $\begin{array}{l}\text { Type and prevalence not } \\
\text { defined }\end{array}$ & $\begin{array}{l}\text { Type } 1 \text { (>80\% in } 2011- \\
2012 \text { ), but type } 2 \text { in- } \\
\text { creased in 2015-2016, } \\
\text { dominated after } 2017\end{array}$ & ND \\
\hline & Morozumi et al. ${ }^{14)}$ & $2002-2019$ & $\begin{array}{l}105 \\
(2018- \\
2019)\end{array}$ & 11.3 & $\begin{array}{l}\text { ST3 and ST14 dominated } \\
\text { during 2002-2016, ST7 } \\
\text { and ST33 dominated } \\
\text { during 2018-2019 }\end{array}$ & $\begin{array}{l}\text { Type } 2 \text { (ST33, ST34, ST7) } \\
\text { dominated during 2018- } \\
\text { 2019, type } 1 \text { (ST3, ST17, } \\
\text { ST19) dominated during } \\
\text { 2012-2016) }\end{array}$ & $\begin{array}{l}\text { A2063G (100\%, } \\
\text { 2018-2019) }\end{array}$ \\
\hline & Suzuki et al. ${ }^{15)}$ & 2016-2017 & 25 & 28 & ND & Type 2, 52.2\% (no MRMP) & Not specified \\
\hline \multirow[t]{2}{*}{$\begin{array}{l}\text { Republic of } \\
\text { Korea }\end{array}$} & Lee et al. ${ }^{11)}$ & $2000-2016$ & 146 & $\begin{array}{l}3.4(2006-2007) / \\
54.1(2010-2012) / \\
84.4(2014-2016)\end{array}$ & ST3 (74.7\%), ST14 (15.1\%) & $\begin{array}{l}\text { Type } 1(70.6 \%) \text {, type } 2 \\
(29.4 \%) ; \text { type } 1 \text { has } \\
\text { decreased (75\% [2006- } \\
2007] \text { to } 50 \% \text { [2014- } \\
2016])\end{array}$ & $\begin{array}{c}\text { A2063G (98.3\%), } \\
\text { A2064G (1.7\%) }\end{array}$ \\
\hline & Lee and Lee ${ }^{74)}$ & 2019-2020 & 148 & 61.5 & ND & ND & A2063G (94.7\%) \\
\hline \multirow[t]{3}{*}{ Taiwan } & Hung et al. ${ }^{75)}$ & 2017-2019 & 226 & 77 & $\begin{array}{l}\text { MSMP: ST14 (53.8\%), ST17 } \\
\text { (28.8\%), ST3 (11.5\%) } \\
\text { MRMP: ST3 (50\%), ST17 } \\
\text { (39.7\%), ST14 (6.9\%) }\end{array}$ & $\begin{array}{l}\text { Type } 1 \text { dominated in MRMP, } \\
\text { Type } 2 \text { domincated in } \\
\text { MSMP }\end{array}$ & $\begin{array}{l}\text { A2063G (82.8\%), } \\
\text { A2063T (16.1\%), } \\
\text { A2064G (1.1\%) }\end{array}$ \\
\hline & Lu et al. ${ }^{76)}$ & 2016 & 180 & 24 & $\begin{array}{l}\text { M 4-5-7-2 (52\%, associated } \\
\text { with MRMP), M4-5-7-3 (27 } \\
\text { \%), M1-5-6-2 (15\%) }\end{array}$ & ND & A2063G (86\%) \\
\hline & Yang et al. ${ }^{45)}$ & 2010-2017 & 471 & 24 & $\mathrm{ND}$ & ND & A2063G (91\%) \\
\hline Germany & $\begin{array}{l}\text { Dumke and } \\
\text { Ziegler }^{77)}\end{array}$ & 2016-2018 & 166 & 3 & ND & ND & A2064 \\
\hline Russia & Voronina et al. ${ }^{78)}$ & $2015-2018$ & 117 & 7 & $\begin{array}{l}\text { M3-5-6-2 (56.8\%), M4-5-7-2 } \\
\text { (43.2\%) }\end{array}$ & ND & A2063G (7\%) \\
\hline Slovenia & Kogoj et al. ${ }^{79)}$ & 2006-2015 & 872 & 0.8 & $\begin{array}{l}\text { M3-5-6-2, M3-6-6-2 predo- } \\
\text { minated in 2009-2011 } \\
(77.0 \%), \text { M4-5-7-2 in 2013- } \\
2015(71.6 \%)\end{array}$ & $\begin{array}{l}\text { Type } 2 \text { predominated } \\
\rightarrow \text { type } 1 \text { predominated } \\
\text { after } 2013\end{array}$ & Not specified \\
\hline Spain & Rivaya et al. ${ }^{80)}$ & 2013-2017 & 138 & 8 & $\begin{array}{l}\text { M4-5-7-2 (50.1\%), M3-5-6-2 } \\
\quad(29.2 \%)\end{array}$ & ND & Not specified \\
\hline Sweden & Gullsby et al. ${ }^{81 \text { a) }}$ & $1996-2017$ & 578 & 0.2 & $\begin{array}{l}\text { M3-5-6-2 (42.4\%), M4-5-7-2 } \\
\text { (37.4\%), M3-6-6-2 (14.9\%); } \\
\text { M4-5-7-2 predominated in } \\
\text { 2016-2017 }\end{array}$ & $\begin{array}{c}\text { Type } 2(57.8 \%), \text { type } 1 \\
(42.2 \%) ; \text { type } 1 \text { predo- } \\
\text { minated in 2016- } 2017\end{array}$ & A2063G \\
\hline Switzerland & Wagner et al. ${ }^{82 \mathrm{l} a)}$ & 2014-2017 & 163 & 9 & $\mathrm{ND}$ & ND & $\begin{array}{l}\text { A2063G (60\%), } \\
\text { A2064G (33.3\%) }\end{array}$ \\
\hline \multirow[t]{2}{*}{ USA } & Waites et al. ${ }^{16)}$ & 2015-2018 & 306 & 6.9 & ND & ND & $\begin{array}{l}\text { A2063G (81.5\%), } \\
\text { A2064G (14.8\%) }\end{array}$ \\
\hline & Xiao et al. ${ }^{17)}$ & $2012-2018$ & 446 & 8.3 & $\begin{array}{c}\text { M3-5-6-2 (41.7\%), M4-5-7-2 } \\
\text { (35.3\%), M3-6-6-2 (16.6\%) }\end{array}$ & $\begin{array}{l}\text { Type } 259.8 \% \text {, MRMP pro- } \\
\text { portion } 12.9 \% \text { in type } 1 \\
\text { and } 5.5 \% \text { in type } 2\end{array}$ & A2063G (86.5\%) \\
\hline Colombia & Copete et al. ${ }^{83) a)}$ & 2011-2013 & 42 & 0 & ND & Type 2 (89.3-96.1\%) & Not specified \\
\hline South Africa & Carrim et al. ${ }^{84)}$ & $2012-2015$ & 33 & 0 & $\begin{array}{l}\text { M3-5-6-2 (44\%), M3/6/6/2 } \\
\text { (38\%), M4-5-7-2 (18\%) }\end{array}$ & Type 2 (61\%), type 1 (29\%) & Not specified \\
\hline
\end{tabular}


macrolide-sensitive MP was 0.004/0.008, 0.002/0.004, and $0.00025 / 0.0005$, respectively. ${ }^{19)}$ However, this test is not useful to clinical practice because it requires long time ( $>2$ weeks) for bacterial growth.

The PCR method can be performed to identify macrolide resistance using cultured MP isolates or DNA extracted from nasopharyngeal samples. ${ }^{3,20)}$ The PCR products can be sequenced to identify the transitions in domain $\mathrm{V}$ of the $23 \mathrm{~S}$ rRNA gene that are associated with macrolide resistance. Multiplexed PCR test has been widely used to detect MP from respiratory samples in many hospitals in Korea, but the sequencing test to identify macrolide resistance is not available in clinical practice. In Japan, it is recommended that clinicians should assess the efficacy of macrolides and consider to collect samples available to clarify the susceptibility of the causative organism in the absence of defervescence 48-72 hours after the start of macrolide therapy. ${ }^{21)}$ It is needed to introduce clinically available tests to detect macrolide resistance of MP.

\section{Uncertain impact of macrolide resistance on clinical course}

Since the first macrolide resistance of MP was isolated from clinical samples obtained from children with pneumonia in Japan in 2000, it has been suggested that macrolide resistance can be associated with severe respiratory symptoms in children. However, the clinical relevance of resistant strains is largely debated, because it is not clarified whether resistant strains are related with severe or prolonged disease. ${ }^{22-27)}$ A recent study reported that some of macrolide-resistant MP pneumonia patients who received macrolide treatment showed clinical failure with progress of disease. ${ }^{27)}$ In contrast, it has been reported that macrolide resistance alone does not affect clinical course. ${ }^{3)} \mathrm{A}$ multicenter study showed that the time to defervescence after initiation of macrolide therapy in MP pneumonia children was longer in the macrolide-resistant group than in the macrolidesusceptible group (5.7 days vs. 4.1 days). However, multivariate logistic regression analysis revealed that the presence of extrapulmonary signs, homogeneous lobar consolidation, and parapneumonic effusion was responsible for prolonged fever $\geq 7$ days following macrolide treatment regardless of macrolide resistance. ${ }^{3)}$ In a Taiwan study, while intensive care unit (ICU) cases $(n=34)$ were associated with more pleural effusion, longer fever duration, and longer hospital stay, compared with non-ICU cases $(n=291)$, macrolide resistance was similar in ICU and nonICU groups. ${ }^{23)}$

\section{What to consider when diagnosing MP pneumonia}

As the need for secondary drugs increases, there are concerns about their safety: not only adverse reactions from them, but also their misuse and overuse. Efforts to diagnose MP infection more carefully are necessary to avoid unnecessary exposure to antibiotics or additional therapeutic agents.

\section{Serologic diagnosis}

Diagnosis of MP infection in routine clinical practice has been mainly based on serology, since bacterial culture of this organism takes long time and lacks sensitivity. Several specific antibody tests can be used to measure serum antibodies to MP. The complement fixation test, which was the standard serologic method for the diagnosis of MP infection, is currently not widely used due to nonspecific reactions and lack of sensitivity. ${ }^{28)}$ Alternative formats adapted for commercial serologic assays include indirect immunofluorescence assay, particle agglutination (PA) assay, and enzyme-linked immunoassay (EIA). The PA assay was the most widely used method in Korea until recently, because it is easy to perform and provide quantitative results with acceptable sensitivity. ${ }^{29)}$ However, the PA assay has some disadvantages: ambiguity in the determination of agglutination, nonspecific reactions, and inability to discriminate between $\operatorname{IgG}$ and $\operatorname{IgM}{ }^{30}{ }^{30}$ The EIA can detect IgG and IgM separately, which can be somewhat helpful to distinguish current from past infections. ${ }^{29)}$ Recently, many diagnostic laboratories have replaced the PA tests with EIA for demonstration of MP antibodies. ${ }^{20)}$ The current widely used IgM EIA test has the advantage of being able to diagnose using a single sample, but it is likely to have a falsepositive result and can be detected for a long time after infection. Therefore, in Japanes Guiding Principle, even if IgM is positive, it is recommended to confirm the diagnosis using $\operatorname{IgG}$ tests from paired samples. ${ }^{21)}$ Testing paired samples is practically impossible and is not always necessary for routine MP pneumonia care. In the case of refractory pneumonia, testing IgG from paired samples can be used to confirm the diagnosis of MP infection since it is often more than 1-2 weeks after the onset of illness when determining whether to change the treatment.

\section{Diagnosis using molecular detection}

Molecular diagnostic tests using PCR are more advantageous than culture tests and serologic tests since they can detect the presence of bacterial DNA quickly and more sensitively. ${ }^{14,31,32)}$ In addition, PCR assays can be used to diagnose MP infection earlier than serology tests, particularly in young children and immunocompromised patients who do not produce antibodies. 33) The PCR can also play a complementary role in interpreting the results of serologic tests to exclude the past infections. Because both serology and PCR may occasionally give nonoverlapping false-negative results, a combination of these 2 diagnostic methods would be helpful. ${ }^{20)}$

However, PCR testing using nasopharyngeal specimen or sputum may be positive also in the presence of upper respiratory carriage or asymptomatic infection. PCR cannot distinguish actual infection from carriage or asymptomatic infection. Unfortunately, there is no current diagnostic test that is able to differentiate between asymptomatic carriage and symptomatic infection. ${ }^{32)}$

3. Asymptomatic carriage of MP in the upper respiratory tract Like many other respiratory pathogens, MP can be carried 
asymptomatically in upper respiratory tract. ${ }^{2)}$ Recent studies have demonstrated that asymptomatic carriage of MP is highly prevalent. In a Dutch study, MP DNA was detected in 21\% of asymptomatic healthy children in $16 \%$ of children with respiratory symptoms. The MP detection rates using culture were not significantly different between asymptomatic and symptomatic children (1.0\% vs. $1.6 \%) .{ }^{32)}$ Among symptomatic children, the prevalence of MP by real-time PCR did not differ significantly between children with an upper respiratory infection and a lower respiratory infection (15.9\% vs. $15.6 \%) .{ }^{32}$ ) This suggests that among pneumonia patients with positive MP PCR in nasopharyngeal specimens, some of them are caused by a pathogen other than MP and MP only plays a role as a colonizer. A longitudinal observation of asymptomatic MP carriers revealed that MP bacteria were present for up to 4 months without causing disease. ${ }^{32}$ ) This prolonged shedding of MP seems to be related with that natural immunity against MP does not persist for a long time after MP infection and frequent reinfection is possible in the same person. ${ }^{9)}$

\section{Considering infections caused by other respiratory patho- gens}

When patients with pneumonia who have been empirically treated with macrolide have fever and have no clinical improvement, the possibility of infection with other pathogens should be considered as well as that of macrolide-resistant MP infection. Children with MP infection were found to simultaneously carry many kinds of pathogens in their upper respiratory tract (Table 2). ${ }^{32)}$ These pathogens include the bacteria Staphylococcus pneumoniae, Staphylococcus aureus, Moraxella catarrhalis, and Haemophilus influenzae, and the viruses influenza $\mathrm{A} / \mathrm{B}$, human metapneumovirus, respiratory syncytial virus, parainfluenzavirus, rhinovirus, coronavirus, bocavirus, and adenovirus. $^{20)}$ Recent studies have reported coexistence of MP with other pathogens in children with MP pneumonia. Other pathogens were simultaneously found in 20.5\%-56.1\% of the patients with MP pneumonia. ${ }^{20,34-36)}$ However, the impact of coinfections in MP pneumonia on disease severity is not yet determined. ${ }^{20,37,38)}$

Recently, multiplexed PCR tests for bacterial or viral pathogen of respiratory infections have been widely used in many hospitals, which can be helpful to rule out the possibility of coinfection. However, it can require multiple nasopharyngeal swabs that make young patients and their caregivers discomfort, and additional cost. Since virus panel testing is currently not covered by national health insurance for patients of other ages than neonates, it may not be applied to all patients requiring the tests.

\section{Efficacy of secondary antimicrobial treatment in refractory MP pneumonia}

As macrolide-resistant MP infections have been increasing, the needs and concerns for secondary antibiotic treatment have been rising. In 2 recent randomized studies of children with macrolide-refractory MP pneumonia, the duration of fever in the group with azithromycin plus minocycline was shorter than that in the control group with azithromycin-only (3.2 days vs. 5.4 days, 3.7 days vs. 5.2 days). ${ }^{39,40)}$ In a Japanese study of patients with macrolide-resistant MP pneumonia, the 48-hour defervescence rate was $2 \%, 100 \%$, and $0 \%$ in the macrolide, minocycline, and tosufloxacin groups, respectively. ${ }^{41)}$ This was similar to the results of other observational studies that showed 48-hour defervescence rates in the minocycline group $(87 \%$ 91\%) and macrolide group (44\%-46\%). However, the 48-hour defervescence rate of the tosufloxacin group was conflicting with those of other studies (69\%). ${ }^{42,43)}$ In an observational study of children with MP pneumonia who had persistent fever beyond

Table 2. Viral coinfection in children with macrolide-resistant Mycoplasma pneumoniae pneumonia from studies published from 2018-2020

\begin{tabular}{|c|c|c|c|c|c|c|}
\hline Study & Nation & Study period & $\begin{array}{l}\text { Cases studied } \\
\text { viral coinfection (n) }\end{array}$ & Prevalence & $\begin{array}{l}\text { Associated virus, detection rate } \\
\text { among studied cases }\end{array}$ & Impact on clinical course \\
\hline Zhao et al. ${ }^{84)}$ & China & $2016-2018$ & 60 & $30.0 \%$ & $\begin{array}{l}\text { PIV } 11.7 \%, \text { RSV } 8.3 \% \text {, AdV } 8.3 \% \text {, } \\
\text { IFV } 10 \%\end{array}$ & $\begin{array}{l}\text { Limited effects on the progression and } \\
\text { prognosis of MRMP }\end{array}$ \\
\hline Yan et al. ${ }^{66)}$ & & 2013-2017 & 423 & $42.6 \%^{\mathrm{a})}$ & $\begin{array}{l}\text { PIV } 6.6 \%, \text { RSV 5.7\%, AdV 5.0\%, } \\
\text { IFV } 1.4 \%\end{array}$ & Not mentioned \\
\hline Zhouv ${ }^{24)}$ & & 2016-2019 & $\begin{array}{c}107 \\
(\text { MRMP 60) }\end{array}$ & $56.1 \%{ }^{\mathrm{b})}$ & $\begin{array}{l}\text { ADV } 22.4 \%, \text { PIV 13.1\%, HRV/HEV } \\
11.2 \% \text { b) }\end{array}$ & $\begin{array}{l}\text { Severe clinical course of MP pneumonia } \\
\text { is associated with AdV coinfection. }\end{array}$ \\
\hline Lee and Lee ${ }^{74)}$ & Korea & 2019-2020 & 150 & $42.9 \%$ & AdV, HRV c) & $\begin{array}{l}\text { Development of postinfectious bron- } \\
\text { chiolitis obliterans is associated with } \\
\text { viral coinfection rather than MRMP. }\end{array}$ \\
\hline Yang et al. ${ }^{45)}$ & Taiwan & $2010-2017$ & 336 & $7.1 \%$ & $\begin{array}{l}\text { AdV } 7.1 \%, \text { IFV } 2.4 \% \text {, RSV 0.9\%, } \\
\text { PIV 0.6\% }\end{array}$ & Not mentioned \\
\hline Hung et al. ${ }^{75)}$ & & 2017-2019 & 226 & $17.7 \%$ & HRV $8.4 \%$, AdV 4.0\% & Not mentioned \\
\hline Rivaya et al. ${ }^{80)}$ & Spain & 2013-2017 & 137 & $45.3 \%$ & HRV $21.9 \%$, PIV $8.8 \%$, RSV $8.0 \%$ & Not mentioned \\
\hline Waites et al. ${ }^{16)}$ & USA & $2015-2018$ & 360 & $27.7 \%$ & HRV, HEV, IFV, PIV, AdV & \\
\hline
\end{tabular}

PIV, parainfluenza virus; RSV, respiratory syncytial virus; AdV, adenovirus; IFV, influenza virus; MRMP, macrolide-resistant Mycoplasma pneumoniae; HRV, human rhinovirus; HEV, human rhinoviruses; MP, Mycoplasma pneumoniae.

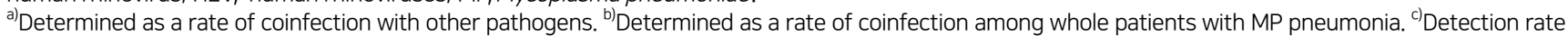
on each respiratory virus was not specified. 
72 hours of macrolide treatment, the secondary treatments such as doxycycline and levofloxacin did not shorten the duration of fever or hospitalization compared to prolonged macrolide treatment. ${ }^{44)}$

It still remains controversial whether delayed effective antimicrobial treatment is associated with prolonged and/or more severe disease. Some studies reported that delayed treatment was associated with prolonged fever after appropriate treatment, fulminant disease, and extrapulmonary manifestations. ${ }^{23,45)}$ In contrast, other studied demonstrated that patients with macrolide-resistant MP pneumonia responded to macrolide treatment without treatment failure. ${ }^{46}$

\section{Safety issues of secondary antimicrobial treatment}

Table 3 describes the dosage and approved age of antibiotics used for the treatment of MP pneumonia.

\section{Tetracyclines}

Tetracyclines are generally safe in children although concerns about adverse reactions, such as gastrointestinal disturbances, esophagitis, photosensitivity, tooth discoloration, still remain. ${ }^{6,47}$ Most concerning side effect is incorporation into calcifying tissues at the time of their administration. The affinity for mineralizing tissue leads to incorporation into calcifying tissues, such as teeth, cartilage, and bone. ${ }^{48)}$ Studies in the 1960s and 1970s showed that repeated administration of tetracycline to neonates and young children was associated with teeth staining. As a consequence, the use of tetracycline in young children was discouraged. Approved age of this drug use varies from country to country: $\geq 12$ years of age in Korea and the United Kingdom, $\geq 8$ years of age in the United States. However, later studies on doxycycline use reported no or only negligible tooth staining even in young children aged 2-8 years. ${ }^{49,50)}$ This difference was attributed to a low affinity for calcium of doxycycline. ${ }^{51)}$ Factors related to tooth discoloration are dosage, duration of treatment, stage of tooth mineralization, and activity of the mineralization process. ${ }^{52)}$ However, previous studies showed that short cycles with limited courses of treatment (less than 6 courses, 6 days per course) caused negligible tooth discoloration in children treated in the first 5 years of life..$^{53)}$

Minocycline is more likely to cause other central nervous system effects (e.g., dizziness, lack of concentration, ataxia, vertigo, and tinnitus associated with weakness, nausea, and vomiting) and pigmentation of various body sites. Although overall adverse reactions are reported more frequently for minocycline, minocycline and doxycycline are generally well tolerated in young children. ${ }^{48)}$

\section{Fluoroquinolones}

Fluoroquinolones have not been widely accepted as safe drug for use in children because of the observation that young animals consistently develop damages on articular surfaces of cartilage after exposure to these drugs. However, fluoroquinolones are generally well-tolerated as supported by recent reports on musculoskeletal safety concerns. Retrospective and prospective assessments of children exposed to fluoroquinolones have not clearly demonstrated the development of lesions consistent with those observed in young animals..$^{54,55)} \mathrm{A}$ recent comparative, unblinded, observational surveillance study has monitored the occurrence of predefined musculoskeletal disorders (arthralgia, arthritis, tendinopathy, and gait abnormality) in children participating in prospective, randomized efficacy trials. Levofloxacin was well tolerated during and for 1 month after therapy. ${ }^{56}$ Even though the incidence of musculoskeletal disorders was greater in levofloxacin group compared with comparator group at 2 months $(2.1 \%$ vs. $0.9 \% ; P=0.04)$ and 12 months $(3.4 \%$ vs. $1.8 \% ; P=0.03$ ) after starting therapy, ${ }^{56)} 85 \%$ of these disorders consisted of reports of arthralgia, without any objective signs of joint disease documented for the children by the investigator at the time of the follow-up visit examination. Moreover, the results of following-up to 5 years after treatment revealed no

Table 3. Recommended treatments for pediatric patients of $M$. pneumoniae pneumonia

\begin{tabular}{|c|c|c|c|c|c|}
\hline Drug & $\begin{array}{c}\text { Route of } \\
\text { administration }\end{array}$ & Drug dose (mg/kg/day), divided dose/day & Maximal dose & Treatment period & Age limit \\
\hline Azithromycin & Oral or IV & $\begin{array}{l}\text { Day 1, } 10 \text { mg/kg/day, \#1; Day 2-5, } 5 \text { mg/kg/day, } \\
\text { \#1 }\end{array}$ & $\begin{array}{l}\text { Day } 1,500 \mathrm{mg} / \text { day; } \\
\text { Day } 2-5,250 \mathrm{mg} / \text { day }\end{array}$ & 3 Days & - \\
\hline Clarithromycin & Oral or IV & $15 \mathrm{mg} / \mathrm{kg} /$ day, \#2 & $1,000 \mathrm{mg} / \mathrm{day}$ & 10 Days & - \\
\hline Roxithromycin & Oral & 5-8 mg/kg/day, \#2 & 300 mg/day & 10 Days & - \\
\hline Levofloxacin & Oral or IV & $\begin{array}{l}\text { Oral: }<5 \text { years of age: } 16-20 \mathrm{mg} / \mathrm{kg} / \mathrm{day}, \# 2 ; \geq 5 \\
\text { years of age: } 8-10 \mathrm{mg} / \mathrm{kg} / \mathrm{day}, \# 1 ; \text { adolescents } \\
\text { with mature musculoskeletal system, } 500 \mathrm{mg} / \\
\text { day, } \# 1 \\
\text { IV: }<5 \text { years of age: } 16-20 \mathrm{mg} / \mathrm{kg} / \text { day, } \# 2 ; \geq 5 \\
\text { years of age: } 8-10 \mathrm{mg} / \mathrm{kg} / \text { day, } \# 1\end{array}$ & $750 \mathrm{mg} /$ day & $\begin{array}{l}\text { 7-14 Days ( } 500 \text { mg/day) } \\
5 \text { Days ( } 750 \text { mg/day) }\end{array}$ & $\leq 18$ Years of age \\
\hline Tosufloxacin & Oral & $12 \mathrm{mg} / \mathrm{kg} /$ day, \#2 & $360 \mathrm{mg} /$ day & 7-14 Days & $\leq 18$ Years of age ${ }^{a)}$ \\
\hline Doxycycline & Oral & $4 \mathrm{mg} / \mathrm{kg} /$ day, \#2 & $200 \mathrm{mg} /$ day & 10 Days & $<12$ Years of age ${ }^{b)}$ \\
\hline Minocycline & Oral or IV & $2-4 \mathrm{mg} / \mathrm{kg} /$ day, $\# 2$ & $400 \mathrm{mg} / \mathrm{day}$ & 7-14 Days & $<12$ Years of age ${ }^{\text {b) }}$ \\
\hline
\end{tabular}

$\mathrm{IV}$, intravenous.

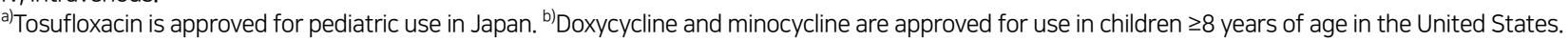


clinically detectable difference between levofloxacin- and comparator-treated children in musculoskeletal toxicity. ${ }^{57)}$ It suggested that risks of cartilage injury with levofloxacin appear to be uncommon, are clinically undetectable during 5 years, or are reversible. ${ }^{57)}$

Other potential adverse reactions of fluoroquinolones, albeit very uncommon in children, include central nervous system adverse effects (seizures, headaches, dizziness, lightheadedness, sleep disorders, and hallucinations) and peripheral neuropathy. However, recent studies have reported that the rates of neurologic events were statistically similar between fluoroquinolone- and comparator-treated children. ${ }^{56,58)}$

Although there has been no compelling published evidence that supports the occurrence of sustained injury to developing bones or joints in children treated with currently available fluoroquinolones, the U.S. Food and Drug Administration (FDA) analysis of ciprofloxacin safety data suggests the possibility of increased musculoskeletal adverse events. The rate of arthropathy in the ciprofloxacin group exceeded that of the comparator group by more than 6\%.59) In 2016, FDA restricted the use of fluoroquinolones even in adults only if no other alternative treatment exists. ${ }^{60)}$ It is because of the potential risks of disabling side effects involving tendons, muscles, joints, nerves, and the central nervous system.

No compelling published evidence to date supports the occurrence of sustained injury to developing bones or joints in children treated with available fluoroquinolone agents; however, FDA analysis of ciprofloxacin safety data suggests the possibility of increased musculoskeletal adverse events.

Tosufloxacin is an oral fluoroquinolone developed by Toyama Chemical Co. Ltd. (Tokyo, Japan) in 1990. The granule form was released for administration to children with otitis media or pneumonia in Japan in January 2010. In Japan, the use of tosufloxacin for children is recommended only for pneumonia when a resistant bacterial infection is suspected and other antimicrobial agents are expected to be ineffective. A Japanese guiding principle has recommended that tosufloxacin may be considered for patients with MP pneumonia who do not respond to macrolide even in children. ${ }^{21)}$ Although no adverse reaction to the musculoskeletal system has been reported in children yet, it has not been approved for use in children in other countries than Japan due to a potential risk of inducing cartilage and joint toxicity in children. Additionally, because the increased use of fluoroquinolones has a risk of emerging resistant bacteria, ${ }^{61)}$ decisions about antibiotic use should be made carefully.

Therefore, when prescribing a fluoroquinolone to a child or adolescent, the risks and benefits of this drug should be reviewed and discussed with patients and their caregivers or legal guardians. They should be aware of side effects, including rash, diarrhea, joint or tendon pain, confusion, or numbness or tingling of extremities while taking the antibiotic.

\section{Conclusions}

It is challenging for clinicians to treat pediatric patients with refractory MP pneumonia. Because diagnostic testing for macrolide-resistant MP infection is currently not clinically available, careful diagnosis is necessary using a combination of serology and molecular detection. In addition, efforts to consider carriage, asymptomatic infection, and infection by other pathogens are necessary to avoid unnecessary exposure to drugs. While some studies have suggested a good efficacy of second-line antimicrobials, further well-designed studies are needed to prove their efficacy on refractory MP pneumonia. Although secondline antimicrobials are generally tolerable, careful decision should be given taking into account the benefits and risks of their use. If prescribed to pediatric patients, monitoring on its adverse events is necessary.

\section{Footnotes}

Conflicts of interest : No potential conflict of interest relevant to this article was reported.

\section{References}

1. Korea Disease Control and Prevention Agency. Guidelines for the antibiotic use in children with lower respiratory tract infections. Cheongju (Korea): Korea Disease Control and Prevention Agency, 2017.

2. Foy HM. Infections caused by Mycoplasma pneumoniae and possible carrier state in different populations of patients. Clin Infect Dis 1993;17 Suppl 1:S37-46.

3. Yoon IA, Hong KB, Lee HJ, Yun KW, Park JY, Choi YH, et al. Radiologic findings as a determinant and no effect of macrolide resistance on clinical course of Mycoplasma pneumoniae pneumonia. BMC Clin Infect Dis 1993;17 Suppl 1:S37-46. Dis 2017;17:402.

4. Bebear C, Pereyre S, Peuchant O. Mycoplasma pneumoniae: susceptibility and resistance to antibiotics. Future Microbiol 2011;6:423-31.

5. Pereyre S, Goret J, Bebear C. Mycoplasma pneumoniae: current knowledge on macrolide resistance and treatment. Front Microbiol 2016;7:974.

6. Lee H, Yun KW, Lee HJ, Choi EH. Antimicrobial therapy of macrolideresistant Mycoplasma pneumoniae pneumonia in children. Expert Rev Anti Infect Ther 2018;16:23-34.

7. Yang HJ, Song DJ, Shim JY. Mechanism of resistance acquisition and treatment of macrolide-resistant Mycoplasma pneumoniae pneumonia in children. Clin Exp Pediatr 2017;60:167-74.

8. Youn YS, Lee SC, Rhim JW, Shin MS, Kang JH, Lee KY. Early additional immune-modulators for Mycoplasma pneumoniae pneumonia in children: an observation study. Infect Chemother 2014;46:239-47.

9. Waites KB, Xiao L, Liu Y, Balish MF, Atkinson TP. Mycoplasma pneumoniae from the respiratory tract and beyond. Clin Microbiol Rev 2017;30:747-809.

10. Principi N, Esposito S. Macrolide-resistant Mycoplasma pneumoniae: its role in respiratory infection. J Antimicrob Chemother 2013;68:506-11.

11. Lee JK, Lee JH, Lee H, Ahn YM, Eun BW, Cho EY, et al. Clonal expansion of macrolide-resistant sequence type 3 Mycoplasma pneumoniae, South Korea. Emerg Infect Dis 2018;24:1465-71.

12. Okubo Y, Michihata N, Morisaki N, Uda K, Miyairi I, Ogawa Y, et al. Recent trends in practice patterns and impact of corticosteroid use on pediatric Mycoplasma pneumoniae-related respiratory infections. Respir Investig 2018;56:158-65. 
13. Katsukawa C, Kenri T, Shibayama K, Takahashi K. Genetic characterization of Mycoplasma pneumoniae isolated in Osaka between 2011 and 2017: decreased detection rate of macrolide-resistance and increase of $\mathrm{p} 1$ gene type 2 lineage strains. PLoS One 2019;14:e0209938.

14. Morozumi M, Takahashi T, Ubukata K. Macrolide-resistant Mycoplasma pneumoniae: characteristics of isolates and clinical aspects of communityacquired pneumonia. J Infect Chemother 2010;16:78-86.

15. Suzuki S, Konno T, Shibata C, Saito H. Low incidence of macrolideresistant Mycoplasma pneumoniae between april 2016 and march 2017 in Akita prefecture, Japan. Jpn J Infect Dis 2018;71:477-8.

16. Waites KB, Ratliff A, Crabb DM, Xiao L, Qin X, Selvarangan R, et al. Macrolide-resistant Mycoplasma pneumoniae in the United States as determined from a national surveillance program. J Clin Microbiol 2019;57:e00968-19.

17. Xiao L, Ratliff AE, Crabb DM, Mixon E, Qin X, Selvarangan R, et al. Molecular characterization of Mycoplasma pneumoniae Isolates in the United States from 2012 to 2018. J Clin Microbiol 2020;58:e00710-20.

18. Narita M, Okazaki N, Ohya H, Ishida T, Miyashita N, Yamazaki T, et al. Proposed antibiotic breakpoints on Mycoplasma pneumoniae clinical isolates concerning macrolide and lincosamide antibiotics. Jpn J Mycoplasmol 2008;35:59-60.

19. Oishi T, Takahashi K, Wakabayashi S, Nakamura Y, Ono S, Kono M, et al. Comparing antimicrobial susceptibilities among mycoplasma pneumoniae isolates from pediatric patients in japan between two recent epidemic periods. Antimicrob Agents Chemother 2019;63:e02517-18.

20. Quanquin NM, Cherry JD. Mycoplasma and ureaplasma infections. In: Cherry JD, Harrison GJ, Kaplan SL, Steinbach WJ, Hotez PJ, editors. Feigin and Cherry's textbook of pediatric infectious diseases. Philadelphia (PA): Elsevier, 2019:1976-2003.

21. Committee of Japanese Society of Mycoplasmology. Guiding principles for treating Mycoplasma pneumoniae pneumonia [Internet]. Committee of Japanese Society of Mycoplasmology; 2014 [cited 2020 Jun 14]. Available from: http://square.umin.ac.jp/ssm/shisin.pdf.

22. Cardinale F, Chironna M, Chinellato I, Principi N, Esposito S. Clinical relevance of Mycoplasma pneumoniae macrolide resistance in children. J Clin Microbiol 2013;51:723-4.

23. Lee KL, Lee CM, Yang TL, Yen TY, Chang LY, Chen JM, et al. Severe Mycoplasma pneumoniae pneumonia requiring intensive care in children, 2010-2019. J Formos Med Assoc 2021;120(1 Pt 1):281-91.

24. Zhou Y, Wang J, Chen W, Shen N, Tao Y, Zhao R, et al. Impact of viral coinfection and macrolide-resistant mycoplasma infection in children with refractory Mycoplasma pneumoniae pneumonia. BMC Infect Dis 2020;20:633.

25. Zhou Y, Zhang Y, Sheng Y, Zhang L, Shen Z, Chen Z. More complications occur in macrolide-resistant than in macrolide-sensitive Mycoplasma pneumoniae pneumonia. Antimicrob Agents Chemother 2014;58:1034-8.

26. Wu HM, Wong KS, Huang YC, Lai SH, Tsao KC, Lin YJ, et al. Macrolideresistant Mycoplasma pneumoniae in children in Taiwan. J Infect Chemother 2013;19:782-6.

27. Cheong KN, Chiu SS, Chan BW, To KK, Chan EL, Ho PL. Severe macrolide-resistant Mycoplasma pneumoniae pneumonia associated with macrolide failure. J Microbiol Immunol Infect 2016;49:127-30.

28. Jacobs E. Serological diagnosis of Mycoplasma pneumoniae infections: a critical review of current procedures. Clin Infect Dis 1993;17 Suppl 1:S79-82.

29. Yoo SJ, Oh HJ, Shin BM. Evaluation of four commercial IgG- and IgMspecific enzyme immunoassays for detecting Mycoplasma pneumoniae antibody: comparison with particle agglutination assay. J Korean Med Sci 2007;22:795-801.

30. Barker CE, Sillis M, Wreghitt TG. Evaluation of Serodia Myco II particle agglutination test for detecting Mycoplasma pneumoniae antibody: comparison with mu-capture ELISA and indirect immunofluorescence. J Clinic Pathol 1990;43:163-5.

31. Templeton KE, Scheltinga SA, Graffelman AW, Van Schie JM, Crielaard JW, Sillekens P, et al. Comparison and evaluation of real-time PCR, realtime nucleic acid sequence-based amplification, conventional PCR, and serology for diagnosis of Mycoplasma pneumoniae. J Clin Microbiol
2003;41:4366-71.

32. Spuesens EB, Fraaij PL, Visser EG, Hoogenboezem T, Hop WC, van Adrichem LN, et al. Carriage of Mycoplasma pneumoniae in the upper respiratory tract of symptomatic and asymptomatic children: an observational study. PLoS Med 2013;10:e1001444.

33. Kim NH, Lee JA, Eun BW, Shin SH, Chung EH, Park KW, et al. Comparison of polymerase chain reaction and the indirect particle agglutination antibody test for the diagnosis of Mycoplasma pneumoniae pneumonia in children during two outbreaks. Pediatr Infect Dis J 2007; 26:897-903

34. Jain S, Williams DJ, Arnold SR, Ampofo K, Bramley AM, Reed C, et al. Community-acquired pneumonia requiring hospitalization among U.S. children. NEng J Med 2015;372:835-45.

35. Ma YJ, Wang SM, Cho YH, Shen CF, Liu CC, Chi H, et al. Clinical and epidemiological characteristics in children with community-acquired mycoplasma pneumonia in Taiwan: a nationwide surveillance. J Microbiol Immunol Infect 2015;48:632-8.

36. Michelow IC, Olsen K, Lozano J, Rollins NK, Duffy LB, Ziegler T, et al. Epidemiology and clinical characteristics of community-acquired pneumonia in hospitalized children. Pediatrics 2004;113:701-7.

37. Han MS, Yun KW, Lee HJ, Park JY, Rhie K, Lee JK, et al. Contribution of co-detected respiratory viruses and patient age to the clinical manifestations of Mycoplasma pneumoniae pneumonia in children. Pediatr Infect Dis J 2018;37:531-6.

38. Chiu CY, Chen CJ, Wong KS, Tsai MH, Chiu CH, Huang YC. Impact of bacterial and viral coinfection on mycoplasmal pneumonia in childhood community-acquired pneumonia. J Microbiol Immunol Infect 2015; 48:51-6.

39. Li J, Wang X, Wang M, Wang C, Song G. Analyze on the influence of minocycline combined with azithromycin on serum CRP, D-Dimer and lung function in the children with refractory mycoplasma pneumonia. Chin J Biochem Pharm 2017;37:102-5.

40. Han X, Miao N, Wen H, Wang C. Minocycline in children with macrolide-resistant Mycoplasma pneumoniae pneumonia. J Pediatr Pharm 2016;22:17-9.

41. Ishiguro N, Koseki N, Kaiho M, Ariga T, Kikuta H, Togashi T, et al. Therapeutic efficacy of azithromycin, clarithromycin, minocycline and tosufloxacin against macrolide-resistant and macrolide-sensitive Mycoplasma pneumoniae pneumonia in pediatric patients. PLoS One 2017; 12:e0173635.

42. Kawai Y, Miyashita N, Kubo M, Akaike H, Kato A, Nishizawa Y, et al. Therapeutic efficacy of macrolides, minocycline, and tosufloxacin against macrolide-resistant Mycoplasma pneumoniae pneumonia in pediatric patients. Antimicrob Agents Chemother 2013;57:2252-8.

43. Okada T, Morozumi M, Tajima T, Hasegawa M, Sakata H, Ohnari S, et al. Rapid effectiveness of minocycline or doxycycline against macrolideresistant Mycoplasma pneumoniae infection in a 2011 outbreak among Japanese children. Clin Infect Dis 2012;55:1642-9.

44. Ha SG, Oh KJ, Ko KP, Sun YH, Ryoo E, Tchah H, et al. Therapeutic Efficacy and safety of prolonged macrolide, corticosteroid, doxycycline, and levofloxacin against macrolide-unresponsive Mycoplasma pneumoniae pneumonia in children. J Korean Med Sci 2018;33:e268.

45. Yang TI, Chang TH, Lu CY, Chen JM, Lee PI, Huang LM, et al. Mycoplasma pneumoniae in pediatric patients: do macrolide-resistance and/or delayed treatment matter? J Microbiol Immunol Infect 2019; 52:329-35.

46. Suzuki S, Yamazaki T, Narita M, Okazaki N, Suzuki I, Andoh T, et al. Clinical evaluation of macrolide-resistant Mycoplasma pneumoniae. Antimicrob Agents Chemother 2006;50:709-12.

47. Carris NW, Pardo J, Montero J, Shaeer KM. Minocycline as a substitute for doxycycline in targeted scenarios: a systematic review. Open Forum Infect Dis 2015;2:ofv178.

48. Smith K, Leyden JJ. Safety of doxycycline and minocycline: a systematic review. Clin Ther 2005;27:1329-42.

49. Todd SR, Dahlgren FS, Traeger MS, Beltran-Aguilar ED, Marianos DW, Hamilton C, et al. No visible dental staining in children treated with doxycycline for suspected Rocky Mountain Spotted Fever. J Pediatr 
2015;166:1246-51.

50. Volovitz B, Shkap R, Amir J, Calderon S, Varsano I, Nussinovitch M. Absence of tooth staining with doxycycline treatment in young children. Clin Pediatr 2007;46:121-6.

51. Forti G, Benincori C. Doxycycline and the teeth. Lancet 1969;1:782.

52. Sanchez AR, Rogers RS 3rd, Sheridan PJ. Tetracycline and other tetracycline-derivative staining of the teeth and oral cavity. Int J Dermatol 2004;43:709-15.

53. Abramson JS, Givner LB. Should tetracycline be contraindicated for therapy of presumed Rocky Mountain spotted fever in children less than 9 years of age? Pediatrics 1990;86:123-4.

54. Burkhardt JE, Walterspiel JN, Schaad UB. Quinolone arthropathy in animals versus children. Clin Infect Dis 1997;25:1196-204.

55. Yee CL, Duffy C, Gerbino PG, Stryker S, Noel GJ. Tendon or joint disorders in children after treatment with fluoroquinolones or azithromycin. Pediatr Infect Dis J 2002;21:525-9.

56. Noel GJ, Bradley JS, Kauffman RE, Duffy CM, Gerbino PG, Arguedas A, et al. Comparative safety profile of levofloxacin in 2523 children with a focus on four specific musculoskeletal disorders. Pediatr Infect Dis J 2007;26:879-91.

57. Bradley JS, Kauffman RE, Balis DA, Duffy CM, Gerbino PG, Maldonado $\mathrm{SD}$, et al. Assessment of musculoskeletal toxicity 5 years after therapy with levofloxacin. Pediatrics 2014;134:e146-53.

58. Bradley JS, Arguedas A, Blumer JL, Saez-Llorens X, Melkote R, Noel GJ. Comparative study of levofloxacin in the treatment of children with community-acquired pneumonia. Pediatr Infect Dis J 2007;26:868-78.

59. U.S. Food and Drug Administration. Clinical review for new drug applications 19-537/S-049, 20-780/S-013, 19-847/S-027, and 19-857/S031. Silver Spring (MD): U.S. Food and Drug Administration, 2020.

60. Jackson MA, Schutze GE. The use of systemic and topical fluoroquinolones. Pediatrics 2016;138:e20162706.

61. Takeuchi N, Ohkusu M, Hoshino T, Naito S, Takaya A, Yamamoto T, et al. Emergence of quinolone-resistant strains in Streptococcus pneumoniae isolated from paediatric patients since the approval of oral fluoroquinolones in Japan. J Infect Chemother 2017;23:218-23.

62. Guo DX, Hu WJ, Wei R, Wang H, Xu BP, Zhou W, et al. Epidemiology and mechanism of drug resistance of Mycoplasma pneumoniae in Beijing, China: A multicenter study. Bosn J Basic Med Sci 2019;19:288-96.

63. Qu J, Chen S, Bao F, Gu L, Cao B. Molecular characterization and analysis of Mycoplasma pneumoniae among patients of all ages with communityacquired pneumonia during an epidemic in China. Int J Infect Dis 2019;83:26-31.

64. Xue G, Li M, Wang N, Zhao J, Wang B, Ren Z, et al. Comparison of the molecular characteristics of Mycoplasma pneumoniae from children across different regions of China. PLoS One 2018;13:e0198557.

65. Yan C, Yang H, Sun H, Zhao H, Feng Y, Xue G, et al. Diversity in genotype distribution of Mycoplasma pneumoniae obtained from children and adults. Jpn J Infect Dis 2020;73:14-8.

66. Yan C, Xue G, Zhao H, Feng Y, Li S, Cui J, et al. Molecular and clinical characteristics of severe Mycoplasma pneumoniae pneumonia in children. Pediatr Pulmonol 2019;54:1012-21.

67. Yuan C, Min FM, Ling YJ, Li G, Ye HZ, Pan JH, et al. Clinical characteristics and antibiotic resistance of Mycoplasma pneumoniae pneumonia in hospitalized Chinese children. Comb Chem High Throughput Screen 2018;21:749-54.

68. Zhao F, Li J, Liu J, Guan X, Gong J, Liu L, et al. Antimicrobial susceptibility and molecular characteristics of Mycoplasma pneumoniae isolates across different regions of China. Antimicrob Resist Infect Control 2019;8:143.

69. Zhao F, Liu J, Xiao D, Liu L, Gong J, Xu J et al. Pathogenic analysis of the bronchoalveolar lavage fluid samples with pediatric refractory Mycoplasma pneumoniae pneumonia. Front Cell Infect Microbiol 2020; 10:553739.
70. Akashi Y, Hayashi D, Suzuki H, Shiigai M, Kanemoto K, Notake S, et al. Clinical features and seasonal variations in the prevalence of macrolideresistant Mycoplasma pneumoniae. J Gen Fam Med 2018;19:191-7.

71. Ando M, Morozumi M, Adachi Y, Ubukata K, Iwata S. Multilocus sequence typing of Mycoplasma pneumoniae, Japan, 2002-2016. Emerg Infect Dis 2018;24:1895-901.

72. Kawakami N, Namkoong H, Saito F, Ishizaki M, Yamazaki M, Mitamura K. Epidemiology of macrolide-resistant Mycoplasma pneumoniae by age distribution in Japan. J Infect Chemother 2021;27:45-8.

73. Kenri T, Suzuki M, Sekizuka T, Ohya H, Oda Y, Yamazaki T, et al. Periodic genotype shifts in clinically prevalent Mycoplasma pneumoniae strains in Japan. Front Cell Infect Microbiol 2020;10:385.

74. Lee E, Young Lee Y. Risk factors for the development of post-infectious bronchiolitis obliterans after Mycoplasma pneumoniae pneumonia in the era of increasing macrolide resistance. Respir Med 2020;175:106209.

75. Hung HM, Chuang CH, Chen YY, Liao WC, LiSW, Chang IY, et al. Clonal spread of macrolide-resistant Mycoplasma pneumoniae sequence type-3 and type-17 with recombination on non-P1 adhesin among children in Taiwan. Clin Microbiol Infect 2020;S1198-743X(20)30588-7. https:// doi.org/10.1016/j.cmi.2020.09.035. [Epub].

76. Lu CY, Yen TY, Chang LY, Liau YJ, Liu HH, Huang LM. Multiplelocus variable-number tandem-repeat analysis (MLVA) of macrolidesusceptible and -resistant Mycoplasma pneumoniae in children in Taiwan. J Formos Med Assoc 2020;119:1539-45.

77. Dumke R, Ziegler T. Long-term low rate of macrolide-resistant Mycoplasma pneumoniae strains in Germany. Antimicrob Agents Chemother 2019;63:e00455-19.

78. Voronina EN, Gordukova MA, Turina IE, Mishukova OV, Dymova MA, Galeeva EV, et al. Molecular characterization of Mycoplasma pneumoniae infections in Moscow from 2015 to 2018. Eur J Clin Microbiol Infect Dis 2020;39:257-63.

79. Kogoj R, Praprotnik M, Mrvič T, Korva M, Keše D. Genetic diversity and macrolide resistance of Mycoplasma pneumoniae isolates from two consecutive epidemics in Slovenia. Eur J Clin Microbiol Infect Dis 2018;37:99-107.

80. Rivaya B, Jordana-Lluch E, Fernández-Rivas G, Molinos S, Campos R, Méndez-Hernández M, et al. Macrolide resistance and molecular typing of Mycoplasma pneumoniae infections during a 4 year period in Spain. J Antimicrob Chemother 2020;75:2752-9.

81. Gullsby K, Olsen B, Bondeson K. Molecular typing of Mycoplasma pneumoniae strains in Sweden from 1996 to 2017 and the emergence of a new P1 cytadhesin gene, variant 2e. J Clin Microbiol 2019;57:e004919.

82. Wagner K, Imkamp F, Pires VP, Keller PM. Evaluation of lightmix Mycoplasma macrolide assay for detection of macrolide-resistant Mycoplasma pneumoniae in pneumonia patients. Clin Microbiol Infect 2019;25:383. e5-383.e7.

83. Copete AR, Aguilar YA, Rueda ZV, Vélez LA. Genotyping and macrolide resistance of Mycoplasma pneumoniae identified in children with community-acquired pneumonia in Medellín, Colombia. Int J Infect Dis 2018;66:113-20.

84. Carrim M, Wolter N, Benitez AJ, Tempia S, du Plessis M, Walaza S, et al. Epidemiology and molecular identification and characterization of Mycoplasma pneumoniae, South Africa, 2012-2015. Emerg Infect Dis 2018;24:506-13.

How to cite this article: Cho HK. Consideration in treatment decisions for refractory Mycoplasma pneumoniae pneumonia. Clin Exp Pediatr 2021;64:459-67. https://doi.org/10.3345/cep. 2020.01305 